\title{
THE DIFFERENTIATION IN WORK ENRICHMENT STRATEGIES AND ORGANIZATIONAL CREATIVITY FUNCTION: A PERSPECTIVE FROM THE LEADERS OF THE MINISTRY OF OIL IN IRAQ
}

\author{
HUSSAM MHAIBES* AND HAIDER ALI MAHMOOD \\ College of Administration and Economy, Department of Financial and Banking Science, University of Baghdad Al-Waziriya \\ Campus, Baghdad, 10070 Iraq.
}

*Corresponding author: sabrean2555@gmail.com

Submitted final draft: 26 November 2019 Accepted: 7 February 2020

http://doi.org/10.46754/jssm.2020.07.012

\begin{abstract}
This study aimed to investigate the relationship between work enrichment strategies and the success of organisational innovation in the Ministry of Oil in Iraq. The study was conducted at the headquarters of the Iraqi Ministry of Oil in Baghdad and the units of analysis are the leadership of the ministry of directors of 215 people. Questionnaire method was used to collect the data in accordance with the scientific standards approved in previous studies. To verify the validity and the ability to examine the views of the sample, a series of tests were carried out. The Pearson's correlation with F value, $\mathrm{R}$ squared and beta $(\beta)$ were also used to test the hypothesis. The study revealed that there is a significant effect of the dimensions of enriching the work on organisational innovation. The model of the study showed that there is a correlation between the variables of the study. Meanwhile, the exclusion of the variables of the resources and creativity of the current results is the most powerful model. Therefore, it is advised to pay attention to these two variables in order to make a greater impact on the possibility of developing the innovative process based on the enrichment of labour.
\end{abstract}

Keywords: Work enrichment, workload requirements, organisational innovation.

\section{Introduction}

Innovation and adoption of a course of action that depends entirely on innovative ideas must be considered if the organisations at different levels of size, productivity and the society that deals with it as an external environment want to continue their work and remain in the labour market and gain competitive advantage with sustainability (Yusoff et al., 2016). This is in accordance with the increase in global competition. In order to pay attention to the importance of innovation for prosperity, it is the duty of the organisations to survive, develop and succeed. Therefore, one of the most important and most influential methods that organisation can use to reach the innovative climate and innovative employee is by enriching the work (Olszak et al., 2018).

Enriching the work implies that making changes to the function of the dimensions of the routine and to ensure that the incumbent has the right and the time in an appropriate field to express his ideas. This ultimately leads to innovation in production and provides a kind of independence through which the reactions of the customer are known or a person is received in a timely service. The study focuses on two variables from the report which includes five main dimensions: skill diversity, mission identification, mission importance, independence, feedback and the respondent variable (Zocche et al., 2018).

The conceptual framework of this current study on the Iraqi Ministry of Oil is organisational innovation and its seven dimensions: encouragement and motivation, reciprocity, resource adequacy, freedom of action, work challenges, creativity and workload requirements. The most important justification for the application of this concept in this domain as in the Iraqi Ministry of Oil is because of the oil sector for a country like Iraq which depends almost entirely on this sector (Li et al., 2018). For this model to be effective, it must rely on innovation, processes and production. 


\section{Job Enrichment}

Lyngdoh et al., 2018 carried out a study on the effect of job enrichment schemes on selected construction workers in Nigeria. The aim of the study was to ascertain the impact of job enrichment schemes on workers in the construction industry in Nigeria in order to justify their continued use as catalysts. This study is designed to determine the relative performance of the job enrichment systems used by the selected construction companies in Lagos, Nigeria and the effects of the schemes on the employees of these companies. The targeted community has forty-two project sites and the unit of study was project managers and artisans. The questionnaire was used as a survey tool for data collection. The study concluded that high-performance work enrichment programme lead to increased decision-making, total quality management and training programmes (CastilloVergara et al., 2018).

In other words, (Shang et al., 2019) reported on the job enrichment and individual performance among colleges with special reference to a private university. The aim of the study is to determine the relationship between work enrichment and performance of the individuals. The factors of work enrichment (task importance, task identity \& skill variety) on individual performance were explored with quantitative research in an educational institution. The probability of stratification of random samples is employed to collect data from colleges at the private university in order to estimate the relationship between the three factors towards individual performance. From the exploratory study, a pilot guide was provided to determine the second factor which contributes more to enhancing the performance of individuals in the educational organisation (Secundo et al., 2019).

Furthermore, (Laguía et al., 2019) studied how job enrichment can improve job satisfaction at Sokoine University of Agriculture in Tanzania. The aim of the study was to ascertain whether the work enrichment improves job satisfaction of academic staff at the University of Suqwen
Agriculture. Also, the study aimed to determine the existence of work enrichment practices for academic staff and explore the effects of enriching work on the employee's mental state among faculty members. The design of case study was adopted with a total sample size of 104 individuals which were selected using judgment sampling techniques. Data was collected through questionnaire, interview and document review. Quantitative data were analysed by the statistical package for social sciences (Guo et al., 2018). The results showed that the functional enrichment exists among the academic staff and has a positive effect on the employees' ways of thinking about their jobs. Similarly, there is a link between the basic functional characteristics such as task diversity, task identity, task importance, independence of tasks which are elements of job enrichment and job satisfaction for workers (Awan et al., 2019).

\section{Organisational Creativity}

A study on creativity in smaller organisations conducted by Nayak, 2008 aimed to investigate how different levels of innovation may affect small organisations. This study focused on innovation in terms of levels and what factors affect it in small organisations. When designing the study, a qualitative approach was selected with a case study. Through multiple case studies, experimental data were collected. Three small organisations were investigated from the community of study (Schalock et al., 2018). From the analysis, the study concludes that there is a relationship between regression in organisational structure and individual innovation. It is found also that the loss in the number of staff can be as a result of increased responsibility and more existing employees are self-producers (Lee et al., 2017). In order to overcome constraints, the level of knowledge within the company is critical. If handled correctly, restrictions may also promote individual motivation. Close relationships contribute to a secure climate while it is easy to establish closer relationships in smaller organisations. It was also found that individual motivation among staff was linked to 
the innovative work environment (Zhou, 2015; Yusoff et al., 2016).

Moreover, thestudywasontheunderstanding of organisational creativity through relationships among cross-level variables and creativity in research and development organisations. The aim of the study was to examine the correlations between four variables (field experience, innovative personality, non-controlling supervision, and organisational learning culture) and to understand how innovation relates to each variable, as well as cross-level. This study focused on examination of the association of organisational innovation with innovative personality, experience in the field, non-controlling supervision and organisational learning culture and the correlations across levels in research and development of the organisations. The study concludes that experience in the field and uncontrolled supervision was found to be positively associated with innovation. The Ministry is has been commissioned tasked with major tasks, the most important of which is financing the rest of the sectors and trying to promote them, which have been given much attention in the oil sector as source of assistance (Joo et al., 2016).

This research aimed to review the previous cognitive efforts and the scientific literature to increase the verification and clarification of the nature of these variables, this study focused on the concept of enriching the work and its contribution to the success of organisational innovation. Then, using the quantitative approach, this study verified this logical relationship between the two variables proved by those cognitive efforts. Additionally, this study is divided into related parts: the first part reviewed the previous cognitive efforts of the variables; the second part reviewed the scientific literature; and the third part highlighted the research methodology, the population of the study, the scale used and the statistical techniques.

\section{Methodology}

The exploratory approach to the views of leaders and managers at the headquarters of the Iraqi Oil Ministry in Baghdad is the scientific method used in this study. The method is explored to know their views and make estimation based on the scale of the study. An analytical method is also used to interpret the data collected and then analysed by various statistical means after being proven of its credibility and reliability on the interpretation of the relations between the variables of the study to reach the final outcome. The final result reflects the effects on the field of research and on the interest of academics and researchers. The main hypothesis of the study is that "there is a significant correlation between the dimensions of work enrichment (measured by: skill diversity, task assignment, task importance, independence, feedback) and organisational innovation (measured by: encouragement, motivation, reciprocity, resource adequacy, workload requirements).

\section{Data Collection}

The questionnaire includes a set of section pertaining to the personal, scientific and functional data of the sample. From the questionnaire, the third section was allocated to the main research variables (work enrichment) as an independent variable and its dimensions (skill diversity, task assignment, task importance, independence, feedback). The dimensions of organisational innovation, according to the ESBRA (2015), are encouragement, motivation, reciprocity, resource adequacy, freedom of action, work challenges, creativity and workload requirements.

\section{Population of the Study and Research Sample}

The study was carried out at the headquarters of the Iraqi Ministry of Oil in Baghdad. The study was based on a community of ministry leaders who held positions of responsibility. The study was conducted on a sample of 215 officials who are among the general managers. The percentage of agents of general managers is 3.3\% while that of managers' assistants is $4 \%$, managers made 
up $55 \%$ and $25.6 \%$ was for public officials. The number of male is 152 which accounts for $70.7 \%$ while the remaining $29.3 \%$ is for female. This is a significant proportion. The Ministry's diversity was calculated. The percentage of the diploma certificate holders was $11.4 \%$ and that of the bachelor degree holders was $69.3 \%$.

The percentage of holders of the higher diploma certificate was $3.3 \%$ and that of the master's degree was $10.2 \%$. The percentage of the holders of the bachelor's degrees was higher than the rest of other qualifications and the percentage of higher degrees was fairly good. The age groups were divided by $5 \%$ of the category (under 25 years), $23.7 \%$ (31-35 age group), $15.3 \%$ only (36-40 age group), $15.8 \%$ (41-45 age group), $11.6 \%$ (46- 50 age group), $9.8 \%$ (51-55 age group) and $16.3 \%$ for 56 and above age group. The result of the proportion is also good and the calculation for the Ministry in that, most of the leaders are holders of a bachelor's degree and are within the young age group due to the decline of the last proportion. The experience is due to the system of public service and the age of retirement specified at the age of 63. Finally, the youth group is the largest within the sample.

\section{Results and Discussion}

This part of the study shows the results of the statistical and quantitative analyses of the data collected by the survey tool from the research sample which are the leaders and directors of the Ministry of Oil headquarters. The results will be reviewed in the form of paragraphs. The first paragraph is devoted to describing and diagnosing research variables through statistical tools (weighted mean, standard deviation, coefficient of variance) and the relative importance of the paragraphs and distances. It covers the limits of the answers to the sample within the Likert scale. The second section is allocated to the tests of correlation between the main variables of the study and its dimensions using Pearson Correlation test. The last paragraph is assigned to test for $p$ value. This analysis was carried out after confirming the validity of the scale and statistics through several tests that confirm the distribution of the data. The researcher has the confidence to use the standards and reassurance of the results extracted due to the normal distribution and tests that confirm the stability of the scale.

\section{Descriptive Statistics}

In this part of the study, the results of the description and diagnosis of the variables of the research will be discussed independently of the variables of work enrichment strategies and organisational innovation as follows:

\section{Descriptive Statistics of Job Enrichment}

The dimensions and paragraphs of the independent variable (work enrichment) and the statistical tools used to analyse the results are shown in Table 1. From the statistical results, it is revealed that the independent variable obtained a mean of 3.53 which is higher than the arithmetic mean of 3 and a standard deviation of 0.99. Also, there are independent statistics for each of the five dimensions. A mean of 3.89 is obtained after determining the task which is higher than the arithmetic mean with a standard deviation of 0.88 . This is a good result that indicates the sample agreement on accuracy of the result and the generalisation. The value of coefficient of variance of 0.21 gave it the first place among the five dimensions of relative importance.

The study found that all values exceeded the mean arithmetic mean when observing the computational and standard deviations of the paragraphs after determining the task which reflects the importance of the medium of the sample of these paragraphs. In order to achieve the ministry's interest, the result indicates constructive cooperation and communication in an easy way within the ministry. A mean of 3.26 was obtained after the significance of the task and a standard deviation of 1.01 reflects the sample agreement on the answer and a coefficient of variance of 0.26 as shown in Table 1 . In the same way, this study found that the coefficient of variation is very close to the dimensions. The 
Table 1: Description and diagnosis of subdivisions and paragraphs of job enrichment

\begin{tabular}{|c|c|c|c|c|c|}
\hline \multicolumn{2}{|c|}{ Descriptive Statistics } & \multirow{2}{*}{$\begin{array}{c}\text { Values } \\
0.78\end{array}$} & \multirow{2}{*}{$\begin{array}{c}\begin{array}{c}\text { Coefficient } \\
\text { variation }\end{array} \\
0.22\end{array}$} & \multirow{2}{*}{$\begin{array}{c}\begin{array}{c}\text { Std. } \\
\text { Deviation }\end{array} \\
0.83\end{array}$} & \multirow{2}{*}{ Mean } \\
\hline 1 & The Ministry provides a variety of work experiences & & & & \\
\hline 2 & $\begin{array}{l}\text { The Ministry provides training programmes to } \\
\text { learn new skills and allows the use of many new } \\
\text { technologies. }\end{array}$ & 0.78 & 0.22 & 0.83 & 3.83 \\
\hline 3 & $\begin{array}{l}\text { The Ministry grants various powers and the } \\
\text { possibility of changing tasks }\end{array}$ & 0.75 & 0.25 & 0.86 & 3.38 \\
\hline Tota & & 0.77 & 0.23 & 0.84 & 3.65 \\
\hline 4 & $\begin{array}{l}\text { Tasks are arranged regularly to provide good } \\
\text { cooperation within the Ministry }\end{array}$ & 0.77 & 0.23 & 0.84 & 3.72 \\
\hline 5 & $\begin{array}{l}\text { There is good communication and communication } \\
\text { between presidents and subordinates within the } \\
\text { Ministry }\end{array}$ & 0.77 & 0.23 & 0.90 & 3.83 \\
\hline 6 & $\begin{array}{l}\text { Working in the Ministry is a good opportunity that } \\
\text { gives me a sense of importance. }\end{array}$ & 0.82 & 0.18 & 0.73 & 4.11 \\
\hline Tota & & 0.79 & 0.21 & 0.82 & 3.89 \\
\hline 7 & $\begin{array}{l}\text { The success of the Ministry's work depends on the } \\
\text { individual performance of the tasks. }\end{array}$ & 0.57 & 0.43 & 1.22 & 2.84 \\
\hline 8 & $\begin{array}{l}\text { The function of the staff affects the organisational } \\
\text { decisions in the Ministry. }\end{array}$ & 0.73 & 0.27 & 0.92 & 3.44 \\
\hline 9 & $\begin{array}{l}\text { The functions within the Ministry are intellectually } \\
\text { stimulating and give a sense of accomplishment. }\end{array}$ & 0.74 & 0.26 & 0.90 & 3.50 \\
\hline Tota & & 0.69 & 0.31 & 1.01 & 3.26 \\
\hline 10 & $\begin{array}{l}\text { The employee performs the duties independently } \\
\text { and independently of the direct supervisor. }\end{array}$ & 0.57 & 0.43 & 1.10 & 2.56 \\
\hline 11 & $\begin{array}{l}\text { Staff have the freedom to choose the way they see } \\
\text { fit. }\end{array}$ & 0.64 & 0.36 & 1.07 & 3.00 \\
\hline 12 & $\begin{array}{l}\text { Direct officials give subordinates the freedom to } \\
\text { arrange work. }\end{array}$ & 0.71 & 0.29 & 1.02 & 3.48 \\
\hline 13 & $\begin{array}{l}\text { The functions of the Ministry include a great deal } \\
\text { of responsibility }\end{array}$ & 0.83 & 0.17 & 0.70 & 4.09 \\
\hline Tota & & 0.70 & 0.30 & 0.97 & 3.28 \\
\hline 14 & The Ministry attaches great importance to feedback & 0.75 & 0.25 & 0.87 & 3.55 \\
\hline 15 & $\begin{array}{l}\text { Employees receive information about performance } \\
\text { directly from work. }\end{array}$ & 0.24 & 0.76 & 2.81 & 3.71 \\
\hline 16 & $\begin{array}{l}\text { The Ministry is always working to obtain regular } \\
\text { updates on job performance. }\end{array}$ & 0.77 & 0.23 & 0.83 & 3.56 \\
\hline 17 & $\begin{array}{l}\text { Leaders within the ministry recognize the } \\
\text { satisfaction of the supervisor while doing the work. }\end{array}$ & 0.78 & 0.22 & 0.77 & 3.51 \\
\hline Tota & & 0.63 & 0.37 & 1.32 & 3.58 \\
\hline Inde & endent dimension results & 0.72 & 0.28 & 0.99 & 3.53 \\
\hline
\end{tabular}


fourth analysis is on the relative importance. The arithmetic mean reflects the importance of this dimension in the research sample. They are very much in agreement with the importance of the jobs they perform and their impact on the work of the other employees.

In the case of diversity of skills, the study seeks to examine and measure the diversity of skills among workers. This dimension obtained a weighted mean of 3.65 which indicates a good mean and a standard deviation of 0.82 which reflects the agreement of the sample on this answer and the value of the coefficient of variance of 0.21 gave this dimension to be ranked second relative importance. These results reflect a good agreement among the leaders of the research sample on the importance of skill diversity among subordinates. The fourth dimension which is the independence reflects the extent of the possibility of workers to complete their work freely and independently of the direct charge. This dimension obtained a weighted mean of 3.28 , which is higher than the arithmetic mean and a good standard deviation of 0.97 reflects a large agreement in the sample.

The coefficient of variance of the dimension is 0.30 which made this dimension in the fourth ranking between the dimensions of enrichment work. The result reflects the good situation among the leaders of the targeted population in dealing with subordinates as individuals and not just members of the group. It also helped them to develop their strengths through the allocation of time to train them and teach them while each person has the capabilities and aspirations which are different from other colleagues. Regarding the fifth dimension, the feedback reflects the extent to which the employees' reactions and expectations were obtained. This dimension has a weighted mean of 3.58 , which is higher than the arithmetic mean and has a standard deviation of 1.32. The result indicates a large agreement in the sample for the dimension with value 0.37 . The Table 1 shows the statistics for all paragraphs on the enrichment of the work.

\section{Descriptive Statistics of Organisational Creativity}

The descriptive statistics of the variable, organisational creativity is presented in Table 2. This variable obtained a weighted mean of 3.64 which is higher than the arithmetic mean and with a standard deviation of 0.86 . The result of reflects the severity of the sample responses on this variable. The variable is measured with 30 items which were distributed to seven main dimensions. The first dimension was encouragement and motivation with a weighted mean of 3.65 and a standard deviation of 0.89 and a coefficient of variance of 0.25 . It gives this dimension a fourth relative importance between the dimensions. The result indicates that there is a good response in the sample of the research on this dimension and there exists the importance of leaders to pursue the achievement of the goals. The post-reciprocity has reached the weighted mean of 3.81 as shown in the Table 2 and a good standard deviation of 0.81 and the coefficient of variance of 0.21 . This gave a second order ranking for this paragraph, reflecting the existence of challenges in work and sample agreement. 
Table 2: Description and diagnosis of subdivisions and paragraphs of organisational creativity

\begin{tabular}{|c|c|c|c|c|c|}
\hline & Descriptive Statistics & Values & $\begin{array}{c}\text { Coefficient } \\
\text { variation }\end{array}$ & S.D & Mean \\
\hline 1 & $\begin{array}{l}\text { The active flow of ideas is encouraged. The good } \\
\text { employee is known through their innovation } \\
\text { contributions }\end{array}$ & 0.77 & 0.23 & 0.87 & 3.81 \\
\hline 2 & Failure is permitted if the employee does his best & 0.70 & 0.30 & 1.02 & 3.35 \\
\hline 3 & $\begin{array}{l}\text { Senior management appreciates creative ideas and } \\
\text { recognises innovative works. }\end{array}$ & 0.75 & 0.25 & 0.92 & 3.67 \\
\hline 4 & $\begin{array}{l}\text { There is a great deal of exchange of ideas being } \\
\text { done daily because the tasks of action stimulate this } \\
\text { exchange }\end{array}$ & 0.76 & 0.24 & 0.86 & 3.63 \\
\hline 5 & $\begin{array}{l}\text { Staff participate in discussions on any new work } \\
\text { or design. There is encouragement for continuous } \\
\text { professional development through learning. }\end{array}$ & 0.79 & 0.21 & 0.81 & 3.78 \\
\hline Total & & 0.75 & 0.25 & 0.89 & 3.65 \\
\hline 6 & $\begin{array}{l}\text { Team members support each other at work and in the } \\
\text { face of work and crisis problems. }\end{array}$ & 0.80 & 0.20 & 0.78 & 3.90 \\
\hline 7 & Staff challenge each other's ideas constructively. & 0.76 & 0.24 & 0.84 & 3.51 \\
\hline 8 & $\begin{array}{l}\text { There is a great commitment to work within the } \\
\text { Ministry }\end{array}$ & 0.80 & 0.20 & 0.79 & 3.89 \\
\hline 9 & $\begin{array}{l}\text { Interpersonal work is coordinated in our department's } \\
\text { task force with members of other sections of the } \\
\text { Ministry. }\end{array}$ & 0.80 & 0.20 & 0.78 & 3.94 \\
\hline 10 & $\begin{array}{l}\text { The team complements the work already begun by } \\
\text { others in the Ministry. }\end{array}$ & 0.78 & 0.22 & 0.86 & 3.82 \\
\hline Total & & 0.79 & 0.21 & 0.81 & 3.81 \\
\hline 11 & $\begin{array}{l}\text { There are sufficient resources within the organisation } \\
\text { and suitable for project completion }\end{array}$ & 0.73 & 0.27 & 0.92 & 3.45 \\
\hline 12 & Project budgets are generally adequate. & 0.70 & 0.30 & 0.91 & 3.07 \\
\hline 13 & $\begin{array}{l}\text { The information collected in project research makes } \\
\text { projects more creative. }\end{array}$ & 0.76 & 0.24 & 0.83 & 3.44 \\
\hline Total & & 0.73 & 0.27 & 0.89 & 3.32 \\
\hline 14 & $\begin{array}{l}\text { Staff shall determine the appropriate methods and } \\
\text { procedures for the completion of their work. }\end{array}$ & 0.71 & 0.29 & 1.01 & 3.43 \\
\hline 15 & $\begin{array}{l}\text { Management determines how staff will perform work } \\
\text { tasks and how best to implement them }\end{array}$ & 0.81 & 0.19 & 0.75 & 3.84 \\
\hline 16 & Employees enjoy planning their own business freely. & 0.74 & 0.26 & 0.93 & 3.53 \\
\hline Total & & 0.75 & 0.25 & 0.89 & 3.60 \\
\hline 17 & $\begin{array}{l}\text { Daily tasks are a challenge for the Ministry and the } \\
\text { staff to the importance of these tasks }\end{array}$ & 0.81 & 0.19 & 0.72 & 3.87 \\
\hline 18 & $\begin{array}{l}\text { Staff is challenging the projects currently in the } \\
\text { Ministry. }\end{array}$ & 0.77 & 0.23 & 0.80 & 3.55 \\
\hline 19 & $\begin{array}{l}\text { Working in this Ministry is important and meaningful } \\
\text { to employees. }\end{array}$ & 0.85 & 0.15 & 0.63 & 4.16 \\
\hline
\end{tabular}




\begin{tabular}{|c|c|c|c|c|c|}
\hline 20 & $\begin{array}{l}\text { The Ministry confirms the completion of things in the } \\
\text { way they were always done. }\end{array}$ & 0.78 & 0.22 & 0.83 & 3.72 \\
\hline 21 & $\begin{array}{l}\text { There is intense competition within the Ministry to } \\
\text { prove existence and efficiency }\end{array}$ & 0.78 & 0.22 & 0.84 & 3.85 \\
\hline \multicolumn{2}{|l|}{ Total } & 0.80 & 0.20 & 0.76 & 3.83 \\
\hline 22 & $\begin{array}{l}\text { The functions of the Ministry require innovative } \\
\text { employees because we produce innovative projects. }\end{array}$ & 0.79 & 0.21 & 0.86 & 3.99 \\
\hline 23 & $\begin{array}{l}\text { At the Ministry of Oil employees are encouraged to } \\
\text { take the risk of being innovative }\end{array}$ & 0.75 & 0.25 & 0.88 & 3.53 \\
\hline 24 & $\begin{array}{l}\text { Many businesses within the Ministry require individual } \\
\text { innovation. }\end{array}$ & 0.75 & 0.25 & 0.89 & 3.59 \\
\hline 25 & $\begin{array}{l}\text { There is a dispersion in the daily work of the employee } \\
\text { that prevents innovation }\end{array}$ & 0.73 & 0.27 & 0.91 & 3.39 \\
\hline 26 & $\begin{array}{l}\text { Operational procedures and structures facilitate } \\
\text { innovative processes }\end{array}$ & 0.72 & 0.28 & 0.95 & 3.42 \\
\hline \multicolumn{2}{|l|}{ Total } & 0.75 & 0.25 & 0.90 & 3.58 \\
\hline 27 & \multirow{5}{*}{$\begin{array}{l}\text { Employees have time to do their work } \\
\text { Team members leave work as if they have not } \\
\text { completed everything that can be done. } \\
\text { Stress does not affect the prioritization of tasks } \\
\text { People in this ministry have sufficient time to } \\
\text { implement best practices when they do their work. }\end{array}$} & 0.80 & 0.20 & 0.79 & 3.95 \\
\hline 28 & & 0.80 & 0.20 & 0.75 & 3.76 \\
\hline 29 & & 0.69 & 0.31 & 1.04 & 3.40 \\
\hline 30 & & 0.76 & 0.24 & 0.88 & 3.63 \\
\hline Total & & 0.76 & 0.24 & 0.87 & 3.68 \\
\hline & Variable results & 0.76 & 0.24 & 0.86 & 3.64 \\
\hline
\end{tabular}

The third dimension is the adequacy of the resources. The weighted mean was 3.32 and the value of the standard deviation is 0.89 and the coefficient of variance was 0.27 . This result shows that this dimension in terms of the importance is the last dimension among the dimensions of this variable. The freedom of work is the third dimension with weighted mean of 3.60 and a standard deviation of 0.89 and the coefficient of variance of 0.25 . This gave it a relative importance in the fifth degree between the dimensions of this variable, which in turn reflects the interaction of the sample of the research.

The fifth dimension is the challenges of work which have weighted median value of 3.83 . This good mathematical mean shows the sample agreement on the above paragraphs and standard deviations of 0.76 while the coefficient of variance of 0.20 . This result gave this dimension the first place among other dimensions and it confirms the agreement of the sample by trying to emphasise things agreed upon in enriching the work rather than the things that differ from them. For the sixth dimension, creativity, it obtained a balanced of 3.58 and a standard deviation of 0.90 and a coefficient of variance 0.25 . This gives this dimension the position of sixth among other dimensions. Similarly, a weighted mean of 3.68 and a standard deviation of 0.87 and a coefficient of variance of 0.24 are realized for the seventh dimension of the workload requirements. This gives the dimension the seventh rank among other dimensions.

\section{Correlation Analysis}

The study must test the correlations between the independent variable and the variant of Pearson Correlation before entering into the hypothesis test as shown in Table 3. Thus, there is a significant and positive correlation between the leadership of enrichment work and organisational innovation. The value of correlation is $0.732 * *$ with a significant level of 0.01 . It indicates very large approaching $(+1)$ and the value of Significance of 0.000 which 


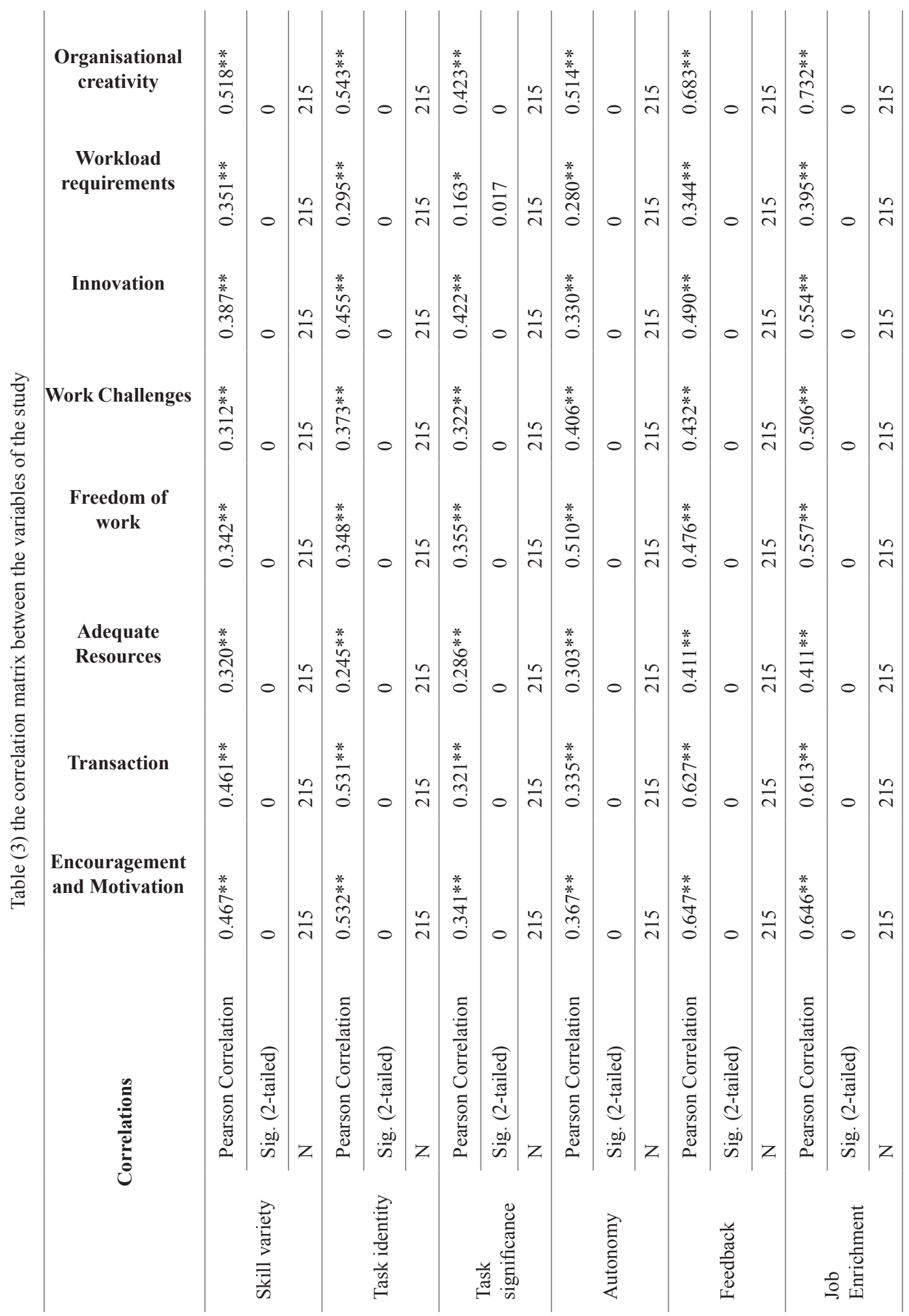


means that the calculated value of $t$ is greater than the scale.

The study found that all these correlations are positive at a significant level of 0.01 when reviewing the correlation values of the five work spans with the variable, organisational innovation. All the significant levels are less than 0.05 ; thus, the calculated $t$ values are greater than the scale of the work's richness and its dimensions with the organisational innovation. Therefore, the study proceeds to the second step in testing for the hypothesis.

\section{Conclusion}

It is clear that organisational innovation is one of the best ways to obtain competitive advantage and stay in the labour market. Similarly, it helps to focus on enriching work as a measure to improve the quality of work and eliminate boredom where an excessive routine has become a necessity to achieve the greatest impact on subordinates. For the purpose of achieving the objectives of this study, the empirical results reveal that there is a great interest in the sample of the research under the research variables. The main hypothesis is confirmed and the initial impressions obtained by the researchers from the preliminary interviews revealed the existence of the problem. Also, the current model emphasised the existence of the correlation between the variables of research. Nevertheless, the exclusion of the variables of resource adequacy and creativity from the current results makes it a powerful model. Finally, these two models should be focused on by the research sample and attention should be paid to them.

\section{Acknowledgements}

Authors would like to thank the reviewers for insightful comments on the manuscript and the University of Baghdad Al-Waziriya Campus for the research facilities.

\section{References}

Awan, U., Sroufe, R., \& Kraslawski, A. (2019). Creativity enables sustainable development: Supplier engagement as a boundary condition for the positive effect on green innovation. Journal of Cleaner Production, 226, 172-185. https://doi.org/10.1016/j. jclepro.2019.03.308.

Bakker, A. B. (2017). Strategic and proactive approaches to work engagement. Organizational Dynamics, 46(2), 67-75. https://doi.org/10.1016/j. jclepro.2019.03.668.

Castillo-Vergara, M., Alvarez-Marin, A., \& Placencio-Hidalgo, D. (2018). A bibliometric analysis of creativity in the field of business economics. Journal of Business Research, 85, 1-9. https://doi. org/10.1016/j.jbusres.2017.12.011.

Guo, L., Decoster, S., Babalola, M. T., De Schutter, L., Garba, O. A., \& Riisla, K. (2018). Authoritarian leadership and employee creativity: The moderating role of psychological capital and the mediating role of fear and defensive silence. Journal of Business Research, 92, 219-230. https:// doi.org/10.1016/j.jbusres.2018.07.034.

Laguía, A., Moriano, J. A., \& Gorgievski, M. J. (2019). A psychosocial study of selfperceived creativity and entrepreneurial intentions in a sample of university students. Thinking Skills and Creativity, 31, 44-57. https://doi.org/10.1016/j.tsc.2018.11.004.

Lee, H. W., Choi, J. N., \& Kim, S. (2018). Does gender diversity help teams constructively manage status conflict? An evolutionary perspective of status conflict, team psychological safety, and team creativity. Organizational Behavior and Human Decision Processes, 144, 187-199. https:// doi.org/10.1016/j.obhdp.2017.09.005.

Li, Z., Duverger, P., \& Yu, L. (2018). Employee creativity trumps supervisor-subordinate guanxi: Predicting prequitting behaviors in China's hotel industry. Tourism 
Management, 69, 23-37. https://doi. org/10.1016/j.tourman.2018.05.004.

Lyngdoh, T., Liu, A. H., \& Sridhar, G. (2018). Applying positive psychology to selling behaviors: A moderated-mediation analysis integrating subjective well-being, coping and organizational identity. Journal of Business Research, 92, 142-153.

Joo, B. K., Lim, D. H., \& Kim, S. (2016). Enhancing work engagement: The roles of psychological capital, authentic leadership, and work empowerment. Leadership \& Organization Development Journal, 37(8), 1117-1134.

Nayak, A. (2008). Experiencing Creativity in Organisations: A Practice Approach. Long Range Planning, 41(4), 420-439. https:// doi.org/10.1016/j.lrp.2008.05.001.

Olszak, C. M., Bartuś, T., \& Lorek, P. (2018). A comprehensive framework of information system design to provide organizational creativity support. Information and Management, 55(1), 94-108. https://doi. org/10.1016/j.im.2017.04.004.

Schalock, R. L., Verdugo, M. A., \& van Loon, J. (2018). Understanding organization transformation in evaluation and program planning. Evaluation and Program Planning, 67, 53-60. https://doi. org/10.1016/j.evalprogplan.2017.11.003.
Secundo, G., Del Vecchio, P., Simeone, L., \& Schiuma, G. (2019). Creativity and stakeholders' engagement in open innovation: Design for knowledge translation in technology-intensive enterprises. Journal of Business Research, 0-1. https://doi.org/10.1016/j. jbusres.2019.02.072.

Shang, Y., Chong, M. P. M., Xu, J., \& Zhu, X. (2019). Authentic leadership and creativity in China: The role of students' regulatoryfocused behaviors and supervisors' power sources. Thinking Skills and Creativity, 34, 100592. https://doi.org/10.1016/j. tsc.2019.100592.

Yusoff, H. N., Mohamed, A. F., \& Hadi, A. S. (2016). Sustainable development: What is the role of audit? Journal of Sustainability Science and Management, 11(1), 99-112.

Zocche, L., de Paula, I. C., Kunrath, S. E., Martins, V. L. M., \& Lermen, F. H. (2018). Variables that influence creativity in perception of professionals: A case study in innovative Brazilian companies. Thinking Skills and Creativity, 29, 170-184.

Zhou, J. (2015). The Oxford Handbook of Creativity, Innovation, and Entrepreneurship. Oxford University Press.] 